\title{
TUTELA DIFERENCIADA DOS DIREITOS DAS MULHERES NAS RELAÇÕES DOMÉSTICAS E FAMILIARES ATRAVÉS DA LEI MARIA DA PENHA
}

\author{
DIFFERENTIAL GUARANTEE OF WOMEN'S RIGHTS IN DOMESTIC AND FAMILIAR \\ RELATIONS THROUGH MARIA DA PENHA LAW
}

Eduardo Cambi

Promotor de Justiça no Estado do Paraná. Assessor da Procuradoria-Geral de Justiça do

Paraná. Coordenador do Centro de Estudos e Aperfeiçoamento Funcional (CEAF) do

Ministério Público do Estado do Paraná. Membro colaborador da Comissão de Direitos

Fundamentais (CDDF) do Conselho Nacional do Ministério Público (CNMP).

Coordenador estadual do Movimento Paraná Sem Corrupção. Coordenador Estadual da

Comissão de Prevenção e Controle Social da Rede de Controle da Gestão Pública do

Paraná. Pós-doutor em direito pela Università degli Studi di Pavia. Doutor e mestre em Direito pela UFPR. Professor da Universidade Estadual do Norte do Paraná (UENP) e da Universidade Paranaense (UNIPAR). Diretor financeiro da Fundação Escola do Ministério Público do Estado do Paraná (FEMPAR). Diretor de Pesquisa do Instituto Paranaense de

Direito Processual. Foi assessor de Pesquisa e Política Institucional da Secretaria de

Reforma do Judiciário do Ministério da Justiça (2012-2014). Pesquisador dos seguintes temas: Direitos fundamentais, Jurisdição constitucional, Ministério Público, Novo Código de Processo Civil, Provas, Cidadania e Educação em Direitos Humanos. E-mail: eduardocambi@hotmail.com

Emmanuella Denora

Mestranda em Ciência Jurídica, na linha de pesquisa Função Política, pela Universidade Estadual do Norte do Paraná (UENP - 2016); Advogada; bacharel em Direito pela Universidade Estadual de Londrina (UEL - 2008); pós-graduada em Direito do Estado pela Universidade Estadual de Londrina (UEL - 2009). Professora de Direito

Constitucional, Direito Processual Penal e de Direito Penal. Pesquisadora de questões de gênero e Direitos Humanos. E-mail: denora.adv@gmail.com

Recebido em: 16/09/2016

Aprovado em: 03/05/2017

Doi: $10.5585 / \mathrm{rdb} . v 17 \mathrm{i} 7.484$

RESUMO: O presente texto discorre sobre o reconhecimento jurídico e político dos direitos das mulheres, que no Brasil, advindo com a Lei Maria da Penha (2006), colocou a discussão sobre gênero em pauta jurídica, bem como chamou a atenção sobre as várias formas de violências sofridas e enfrentadas pelas mulheres, a partir do ambiente privado, o próprio lar, a serem reproduzidas em ambientes públicos. Utiliza-se a metodologia dialética, para, considerando os dez anos de vigência da lei em estudo, versar sobre as questões de igualdade material e ressalta a importância da Lei 11.340/2006 como instrumento de ação afirmativa para o enfrentamento de problemas de inclusão social. Aborda, ainda, os aspectos diferenciados dessa lei, sob a perspectiva democratizante dos direitos das minorias e da percepção do Direito como meio de fomento para uma cultura de valorização e respeito aos direitos humanos.

Palavras-Chave: Direitos das Mulheres; Lei Maria da Penha; Aspectos Processuais da Lei Maria da Penha. 


\begin{abstract}
This paper is about the legal and political recognition of women's right that in Brazil, arising mainly with the Maria da Penha Law (in 2006), placed the discussion about gender on the agenda and called attention to the many forms of violence suffered and faced by women from the private environment to be repeated in public places. The dialectical methodology is used to, considering the ten years of validity of the law under study, dealing with the equality issues and material constitutionality of affirmative action promoted with the legislation, and addresses the question of answering social problems. It also concerns with the the matter filtered through democratizing inclusion of minority rights and the perception of law as material equality developer of a culture of human rights formation.
\end{abstract}

Key Words: Women's Rights; Maria da Penha Law; Maria de Penha Law Procedures.

SUMÁRIO: Introdução; 1. Breve relato do tratamento das mulheres na História. O caso de Maria da Penha; 2. Direitos das mulheres como direitos humanos; 3. Lei Maria da Penha como instrumento de ação afirmativa; 4. Constitucionalidade da Lei Maria da Penha; 5. Tutela diferenciada na Lei Maria da Penha; Conclusão; Referências bibliográficas.

\title{
INTRODUÇÃO
}

A história das mulheres é uma história de esquecimento. A história da humanidade, da forma como é tradicionalmente apresentada, as exclui da participação efetiva na vida pública e política, relegando a elas sequer nota de rodapé, ignorando suas participações e contribuições tanto em ambientes públicos mas sobretudo silenciando sobre o papel privado. Norteada pelo machismo estrutural, deixa de lado importantes contribuições das mulheres tanto nos ambientes públicos quanto privados. A historiografia feminista permite assim resgatar e a incluir esse grupo ainda considerado minoritário e inferior, não obstante sua quantidade numérica substancial, pela desestruturação da perspectiva histórico-patriarcal.

No Brasil, o reconhecimento jurídico e político de lutas históricas do movimento feminista advém especialmente com a Lei Maria da Penha, que coloca a discussão sobre gênero em pauta. Essa lei também chama a atenção sobre as várias formas de violências sofridas e enfrentadas pelas mulheres.

A Lei 11.340/2006 é um referencial legal do e para o movimento feminista, sendo inovadora ao perceber juridicamente que as violências sofridas pelas mulheres a partir do ambiente privado devem ser politizadas. Foi estruturada em perspectiva interdisciplinar, trazendo um conjunto sistematizado de proteção ao regulamentar matérias de Direito de Família, Penal e Processual. Dessa forma, criou, ainda, um procedimento diversificado ao prever, por exemplo, medidas protetivas de urgência e proibir a aplicação subsidiária da Lei 9.099/95.

Com efeito, produziu um ambiente de compromisso e empatia às questões de gênero para defender a hipossuficiência relacionadas às violências domésticas e familiares. Com isso, a Lei 11.340/2006 acabou por reconhecer oficialmente que existe, no Brasil, permissividade social em relação aos direitos das mulheres tendo como causa histórica a dominação arraigada por uma sociedade machista.

Nesse trabalho, através do método dialético, procura-se abordar o caminho de conquistas sobre gênero, mais especificamente sobre os direitos das mulheres, tendo como enfoque a Lei Maria da Penha, na perspectiva dos direitos humanos, com o intuito de destacar os aspectos processuais diferenciados trazidos nessa legislação. 


\section{BREVE RELATO DO TRATAMENTO DAS MULHERES NA HISTÓRIA}

Quando se afirma que a história das mulheres é uma história de esquecimento, é em razão do lugar que restou reservado às mulheres dentro da ciência da memória, relegando-as a condição de mínima ou quase nenhuma representatividade.

Desde a filosofia grega, prepondera-se o discurso masculino, sendo a diferença excluída. Aristóteles definiu a mulher como falha da natureza (uma mulher inteligente seria um fato contranatural). Atribuía aos homens as características da beleza, força e inteligência, enquanto as mulheres eram caracterizadas como seres fracos por natureza, cabendo a elas a reclusão em casa, o convívio com os escravos e animais no universo de infraestrutura (Oikos $=$ de administração da vida, ambiente do lar) e da vida Zoé (vida viva, para procriação), sendo o corpo da mulher associado ao dos escravos e dos animais (TIBURI, 2016). De acordo com Michelle Perrot (2016, p.23), é Aristóteles quem estabelece de maneira mais radical a superioridade masculina, dizendo que as mulheres se movem nas fronteiras da civilidade e da selvageria, sendo uma ameaça potencial à vida coletiva harmoniosa, sendo um homem incompleto, inacabadas, devendo-se esperar delas que sejam, na geração, um vaso de bom receptáculo.

$\mathrm{Na}$ Idade Média, a mulher continua a ser pensada como falha da natureza, razão pela qual as vozes das mulheres foram silenciadas. São mencionadas na criação, associadas a uma imagem perversa, inconfiável, relacionadas à figura bíblica pecadora de Eva. Os filósofos medievais da Igreja pregavam a dominação dos corpos das mulheres, ao considerar sua carne o lugar do pecado. O livro Malleus Malleficarum, escrito em 1487, foi o ápice da perseguição às mulheres ao personificar o mal, o diabo, no corpo da mulher. Não obstante não ser reconhecido pelos seus pares como um trabalho de pesquisa honesto, atingiu enorme popularidade, tendo aproximadamente vinte edições em trinta anos, o que para os padrões do período o torna de fato um best seller. Com a legitimação de seu conteúdo, promoveu-se uma maciça queima de mulheres condenadas ao "fogo purificador", sendo estimadas cem mil o número de suas vítimas, 90\% mulheres. Não obstante as discordâncias doutrinárias, os protestantes apoiavam os católicos sobre a nocividade das feiticeiras, explicando assim a Alemanha na geografia das fogueiras (PERROT, 2016, p. 89).

Immanuel Kant (1724-1804), figura central da filosofia moderna, por sua vez, dá às mulheres a condição de naturalmente servirem para enfeitar. Associa as mulheres ao belo, e os homens ao sublime - eles podem agradar e desagradar ao mesmo tempo, enquanto elas se prestam unicamente para agradar (LINO, 2008). A atuação intelectual da mulher não é encantadora, e a misoginia uma característica propalada nas esferas de conhecimento.

No pensamento liberal clássico, predomina a teorização de um gênero humano não genérico, composto apenas de veri homines, amputado de sua metade feminina e de sua porção criança: a mulher e o menor são subsumidos em uma comum incapacidade jurídica em matéria de questões públicas. Assim, durante muito tempo a modernidade filosófica pensou o gênero humano pela metade. Com efeito, o universalismo afirmado pelo modelo liberal é limitado e desatento na atribuição e no reconhecimento de uma subjetividade política para todos (PIERUCCI, 2013, p. 111-112). Rousseau, um misógino notório, deixa muito claro seus posicionamentos excludentes no que se refere à mulher na obra "Emílio", onde disserta sobre a formação e educação de crianças - homens, as mulheres não precisam ser educadas. As mulheres, para ele, devem ser o máximo invisíveis, escrevendo a D'Alambert que "uma mulher que se mostra se desonra. [...] A audácia de uma mulher é sinal certo de sua vergonha" (PERROT, 2016, p. 128).

No Brasil-Colônia, a educação era reservada apenas aos homens. A mulher deveria obediência ao pai e ao marido, vivendo enclausurada no lar e na Igreja. somente em 1932 as mulheres conquistaram o direito ao voto. Com a vinda da Corte portuguesa para o Brasil e com a Constituição do Império de 1824, surgiram escolas destinadas à educação das mulheres, embora 
ainda voltadas a trabalhos manuais, cânticos e ensino brasileiro de instrução primária, sendo vedado o convívio delas nas escolas masculinas. No regime das Ordenações portuguesas, não se impunha pena ao marido por castigos corporais à mulher e aos filhos; a mulher não poderia ser testemunha em testamento público; o pátrio poder era exclusividade do marido e quase nenhum ato da vida civil poderia ser praticado sem o consentimento do homem. O Código Civil de 1916 manteve esse regime conservador de direitos, sendo a mulher considerada incapaz do ponto de vista civil, sendo comparadas aos então nominados silvícolas e aos menores impúberes. Por exemplo, o art. 240 do Código Civil, na sua redação original, afirmava: "A mulher assume, pelo casamento, com os apelidos do marido, a condição de sua companheira, consorte e auxiliar nos encargos da família". As mulheres somente adquiriram o direito ao voto no Brasil, em 1932, pelo decreto $n^{\circ} 21.076$ do Código Eleitoral Provisório.

A construção misógina na história da representação da humanidade veio a modificar-se com Simone de Beauvoir, que desestrutura a "natureza feminina" e observa a questão de secundarização da mulher ao longo da história. Beauvoir afirma que as mulheres são marcadas pelo sexo, uma vez que consideradas secundárias na cultura, na condição de não-sujeito, porque objeto dentro da história, que constrói a mulher. Daí compreender sua célebre frase "Ninguém nasce mulher: torna-se mulher", que questiona o lugar do destino biológico como fundamento para a afirmação da existência de uma natureza feminina. Portanto, enfatiza a ideia da construção do gênero como não essencial, mas histórico, de modo binário, mas basilar para a compreensão que temos hoje a partir das questões de gênero (BEAUVOIR, 2016).

Quando se dá conta da secundarização de sexo não declarado, resultado do discurso oficial corroborado por filósofos e pensadores em toda a história da humanidade, que reproduzem o androcentrismo por meio de legislação, é necessário contabilizar os fatores institucionais da repetição da divisão de gêneros. Também é importante analisar o papel que o Estado possui ao ratificar e reforçar as prescrições e proscrições do patriarcado privado como se público fosse, com a finalidade de gerir e regulamentar a existência quotidiana da unidade doméstica (BOURDIEU, 2012, p. 105).

Assim, o Estado, pela obra dos legisladores e administradores públicos (ao não preverem nem estruturarem, adequadamente, políticas públicas voltadas à afirmação dos direitos das mulheres), acabou por impor, historicamente, a visão ultraconservadora que faz da família patriarcal o princípio e modelo da ordem social como ordem moral, fundamentada na preeminência absoluta dos homens em relação às mulheres, dos adultos sobre as crianças e na identificação da moralidade com a superioridade da força física e o domínio do corpo, lugar de tentações e de desejos. Com isso, os Estados modernos inscreveram no direito, todos os princípios fundamentais da visão androcêntrica. Aliás, o Código Penal brasileiro (Decreto-lei $\mathrm{n}^{\circ}$ 2.848/1940) previa, até ser modificado pela Lei 11.106/2005, a expressão "mulher honesta" como elemento normativo do tipo de atentado ao pudor mediante fraude (art. 215), e o termo "mulher virgem", para definir o crime de sedução (art. 217).

O corpo das mulheres, além de desejado, é necessário que, dentro da ordem patriarcal, seja subjugado, dominado. Em todos os cenários que se observam, a estrutura de dominação reduzindo as mulheres em sua condição de corpos é evidente. Ainda em meados do século XX, de acordo com a historiadora Michelle Perrot,(2016, p. 76-77) a violência do marido, senhor de sua casa e chefe de família, exercida sobre mulher e filhos era algo considerado normal, desde que com moderação, cujas práticas na França vieram a ser reprovadas recentemente, havendo associações, abrigos para mulheres vítimas de violência

A Constituição da República de 1988 representa um giro copernicano para as conquistas formais das mulheres. Se antes elas eram declaradamente consideradas sujeitas de direito a menor, passam a ter, declaradamente, igualdade de direitos e deveres em geral (art. $5^{\circ}$, inc. I, CR), bem como nas obrigações familiares e de planejamento, e o reconhecimento da união estável como entidade familiar (art. 226 e parágrafos, CR). Também a elas garantiu-se que não haveriam 
práticas discriminatórias laborais (art. $7^{\circ}$, inc. XXX, CR), com a clara finalidade de promover a inclusão das mulheres em espaços públicos e legitimá-las em igualdade nos espaços privados, além de considerá-las em igualdade em relação aos homens, cujos efeitos legais vão além dos aspectos meramente declaratórios.

É o caso de Maria da Penha, como ela própria relata em seu livro autobiográfico "Sobrevivi, posso contar" (2012), em que fala da violência que sofreu quando em um relacionamento abusivo, que durou por 23 (vinte e três) anos. Por duas vezes seu então marido tentou assassiná-la, na primeira vez a tiros, em um assalto forjado, que a deixou paraplégica, e posteriormente por eletrocussão e afogamento. Maria da Penha procurou ajuda na Justiça, que levou 19 (dezenove) anos e meio para ter o julgamento de seu agressor finalmente concluído.

Nesse longo período, Maria da Penha, ciente da impunidade pela desproporção e do pouco zelo com a violência doméstica sofrida, buscou meios internacionais de Direitos Humanos e denunciou o Brasil, signatário da Convenção Interamericana para Prevenir, Punir e Erradicar a Violência Contra a Mulher (Convenção de Belém do Pará), alegando que o país tolerava e, portanto, fazia-se também algoz, a violência cometida por Marco Antônio Heredia Viveiros (seu então marido). O caso foi apreciado, em 2001, pela Comissão Interamericana de Direitos Humanos, órgão competente dentro da Organização dos Estados Americanos (OEA), que concluiu que o Estado Brasileiro não cumpriu o previsto no art. $7^{\circ}$ da Convenção do Pará e nos arts. $1^{\circ}, 8^{\circ}$ e 25 da Convenção Americana dos Direitos Humanos, tendo recomendado o prosseguimento e a intensificação do processo de reforma que evite a tolerância estatal e o tratamento discriminatório com respeito à violência doméstica contra a mulher no Brasil e, em especial, "o estabelecimento de formas alternativas às judiciais, rápidas e efetivas de solução de conflitos intrafamiliares, bem como de sensibilização com respeito à sua gravidade e às consequências penais que gera" (JESUS, 2010, p.98).

Foi essa condenação pública decisiva para que o marido de Maria da Penha fosse condenado e para que o governo viesse a se preocupar com a elaboração de uma lei e de outras políticas públicas contra a violência doméstica e familiar contra mulheres.

Foi somente em 2006 que foi publicada a Lei 11.340, conhecida por Lei Maria da Penha, e que traz em seu bojo legal a aliança entre as medidas assistenciais, as de prevenção e as de contenção da violência, além do vínculo da esfera jurídica com os serviços de assistência em rede. Prevê medidas extrapenais gradativas até chegar às penais.

Em razão disso, a Lei 11.340/2006 é considerada pela Organização das Nações Unidas um exemplo de legislação efetiva para o tratamento da violência doméstica contra mulheres ${ }^{1}$.

Apesar dos progressos legislativos, é forçoso que se reconheça que o Direito é um campo onde as transformações se produzem lentamente. O Direito, enquanto instituição, contribui em grande medida para a manutenção do status quo, presente na tradicional hegemonia masculina na sociedade.

Por outro lado, o Direito é um terreno propício ao desenvolvimento de regras que podem dar origem a transformações importantes, inclusive na relação entre os dois sexos (DAHL, 1993, p. 7).

Assim, não basta o reconhecimento legal da proteção da violência doméstica, porque transformações culturais e comportamentais de uma sociedade não se conquistam apenas por

\footnotetext{
${ }^{1}$ CAMPOS, Carmen Hein de; CARVALHO, Salo de. Tensões atuais entre a criminologia feminista e a criminologia crítica: a experiência brasileira. In: Lei Maria da Penha comentada em uma perspectiva jurídico-feminista. Org. Carmen Hein de Campos. Rio de Janeiro: Lumen Juris, 2011. p. 144. Entretanto, para um estudo de direito comparado, conferir: ÁVILA, Thiago André Pierobom (Coord.). Modelos europeus de enfrentamento à violência de gênero. Experiências e representações sociais. Brasília: Escola ESMPU, 2014; GUIMARÃES, Isaac Sabbá; MOREIRA, Rômulo de Andrade. Lei Maria da Penha: aspectos criminológicos, de política criminal e do procedimento penal. $3^{\text {a }}$ ed. Curitiba: Juruá, 2014. p. 55-71; BAKER, Milena Gordon. A tutela da mulher no direito penal brasileiro. Rio de Janeiro: Lumen Juris, 2015. p. 165-194.
}

Revista de Direito Brasileira | São Paulo, SP | v. 17 | n. 7 | p. 221 - 244 | Mai./Ago. 2017 
meio da legislação. Leis sobre igualdade de tratamento não produzem por si só tratamentos igualitários faticamente (ALVES, 2009), sendo indispensável mudar também os hábitos sociais.

\section{DIREITOS DAS MULHERES COMO DIREITOS HUMANOS}

Pode parecer redundante a afirmação de que as mulheres são seres humanos. Porém, a história demonstra que o reconhecimento de seus direitos como direitos humanos não é apenas um simples exercício de lógica dedutiva.

A política de consideração da mulher como sujeito secundarizado ocasionou a necessidade de se afirmar a sua condição de vulnerabilidade ${ }^{2}$, para que o direito seja capaz de fomentar a inclusão e a transformação da realidade social, rompendo as estruturas assimétricas de poder e hegemônicas da dominação masculina.

Quando se reconhece formalmente a igualdade quanto a sexo e/ou gênero, deve-se alcançar o seguinte questionamento: igualdade de quem em relação a quem? Afinal, se o padrão a ser alcançado de igualdade é o masculino, negando-se qualquer manifestação culturalmente aproximada ao que se reconhece como "feminino", igualmente nega-se questões essencialmente ligadas às mulheres, quanto a seus aspectos biológicos reprodutivos e força física diminuta ${ }^{3}$.

De outro modo, em sendo um procedimento de igualização que reconhece e entende a diferença inata do outro, a própria noção de igualdade resta indeterminada, o que implica em um conceito ainda em construção que deve considerar a humanidade fática, o respeito e a aceitação das diferenças.

Aliás, o movimento feminista ao pleitear igualdade é inegavelmente emancipatório às mulheres, mas também o é para os homens. A dominação masculina e o patriarcado como manifestação engessada de comportamentos impostos (v.g., "homem não chora", "homem não faz serviço doméstico", "homem não brocha" etc.) também são cruéis aos homens que não se sentem confortáveis com tais hábitos e os reproduzem por imposições sociais, ficando sujeitos a estigmas inferiorizantes e que a eles também são promotores de secundarização do sujeito.

Entender a construção estrutural patriarcal é base necessária e imprescindível para a maior conscientização e visualização do papel que o gênero, como construção cultural, sujeitou as pessoas a partir da reprodução do habitus (BOURDIEU, 2007, p. 162-211) dominante. Tal construção patriarcal também serve como método de perpetuação do status quo a começar pela divisão socialmente construída entre os sexos, como naturais, evidentes, e adquire, assim, todo um reconhecimento de legitimação.

Por não serem percebidos os mecanismos subjacentes, tais como os que fundamentam a concordância entre as estruturas cognitivas e as sociais, e, por isso, a experiência dóxica do mundo social, os efeitos simbólicos da legitimação (ou de sociodicéia) são imputados a fatores que decorrem da ordem da representação mais ou menos consciente e intencional ("ideologia", “discurso", etc), que constrói o mundo social como depositário de princípios de visão e de divisão sexualizantes (BOURDIEU, 2012, p.17-18).

\footnotetext{
${ }^{2} \mathrm{O}$ conceito de vulnerabilidade, para fins de aplicação da Lei Maria da Penha, resulta da conjugação dos arts. $2^{\circ}, 4^{\circ}$, $5^{\circ}$ e $7^{\circ}$, e, caracterizada a situação de violência doméstica e familiar, independem da sua verificação no caso concreto. Nesse sentido, é importante o Enunciado $\mathrm{n}^{\circ} 14$ do Conselho Permanente de Violência Doméstica e Familiar (COPEVID) do Grupo Nacional de Defesa dos Direitos Humanos (GNDH), vinculado ao Conselho Nacional de Procuradores Gerais de Justiça do Ministério Público dos Estados e da União: "A Lei Maria da Penha aplica-se a todo e qualquer caso de violência doméstica e familiar contra a mulher, independentemente da aferição de sua situação de hipossuficiência ou de vulnerabilidade (artigos $2^{\circ}$ e $4^{o}$ ), sendo alternativos os requisitos $e$ condições previstos nos artigos $5^{\circ}$ e $7^{\circ}$, não cumulativos".

3 "O reconhecimento da 'dignidade corporal' da mulher entraria então em colisão como princípio fundamental do reconhecimento do mérito individual como um motivo de distinção que tem procedência sobre a riqueza ou o nascimento" (PIERUCCI, Antônio Flávio. Ciladas da diferença. Cit. p. 114).
}

Revista de Direito Brasileira | São Paulo, SP | v. 17 | n. 7 | p. 221 - 244 | Mai./Ago. 2017 
Nesse sentido, o Direito também é utilizado para a reprodução do habitus dominante e para a perpetuação do status quo.

Para a superação das desigualdades históricas, e o consequente agrupamento das mulheres como grupo de minoria a ser protegido especialmente a fim de anular a diferenciação cultural imposta pelos tempos na condição de gênero, é importante afirmar a cultura dos direitos humanos.

O Brasil ratificou os mais importantes tratados internacionais de proteção aos direitos humanos ${ }^{4}$, refletindo as reivindicações e os anseios contemporâneos das mulheres, o que permite ultrapassar a ótica sexista e discriminatória, que impede que elas possam exercer com autonomia e dignidade seus direitos fundamentais (PIOVESAN, 2015, p. 383).

No que se refere à violência contra a mulher, em âmbito doméstico e familiar, a vulnerabilidade é ainda maior, pois os agressores são pessoas em quem as mulheres confiam e estão em seu círculo de intimidade.

Conforme pesquisa realizada pela Human Rights Watch $^{5}$, a cada 10 (dez) mulheres vítimas de homicídio no Brasil, 7 (sete) são em relações domésticas. É o mesmo que dizer que $70 \%$ das mortes violentas de mulheres no país são causadas por pessoas que as vítimas não apenas conheciam, mas confiavam e os tinham em proximidade inclusive afetiva.

Além disso, de acordo com pesquisa realizada pelo Movimento Nacional de Direitos Humanos, 66,3\% dos acusados de homicídios contra mulheres são seus parceiros. Dessa maneira, os dados estatísticos mostram índices altíssimos de violência contra as mulheres praticado no ambiente doméstico.

A violência doméstica atinge variadas classes sociais e culturas, não sendo, portanto, "exclusividade" das pessoas menos favorecidas ou mesmo de países emergentes. De acordo com a Organização das Nações Unidas (ONU), a violência doméstica é a principal causa de lesões em mulheres na faixa dos 15-44 anos, globalmente (PIOVESAN, 2015, p.386).

Vale ressaltar que a Convenção Interamericana para Prevenir, Punir, e Erradicar a Violência contra a Mulher (Convenção de Belém do Pará) - adotada pela Assembleia Geral da Organização dos Estados Americanos em 06 de junho de 1994 e ratificada pelo Brasil em 27 de novembro de 1995 - é o primeiro tratado internacional de proteção dos direitos humanos a reconhecer a violência contra as mulheres como um fenômeno generalizado, que alcança sem distinção de raça, classe, religião, idade ou qualquer outra condição, um elevado número de mulheres. A Convenção afirma que a violência contra a mulher constitui grave violação aos direitos humanos e limita, total ou parcialmente, o exercício dos demais direitos fundamentais. Acrescenta que a violência contra a mulher constitui ofensa à dignidade humana, sendo manifestação de relações de poder historicamente desiguais entre mulheres e homens.

A Convenção Interamericana para Prevenir, Punir, e Erradicar a Violência contra a Mulher define, no art. $1^{\circ}$, violência contra a mulher como "qualquer ação ou conduta, baseada no gênero, que cause morte, dano ou sofrimento físico, sexual ou psicológico à mulher, tanto na esfera pública, como na privada". Perceba-se que a Convenção de Belém do Pará cuida de conceituar violência contra a mulher em sentido amplo, para melhor proteger as mulheres em situação de vulnerabilidade.

\footnotetext{
${ }^{4}$ A propósito, destacam-se os seguintes documentos: a) Convenção Interamericana para Prevenir e Punir a Tortura; b) Convenção contra a Tortura e outros Tratamentos Cruéis, Desumanos ou Degradantes, c) Convenção sobre os Direitos da Criança, d) Pacto Internacional dos Direitos Civis e Políticos, e) Pacto Internacional dos Direitos Econômicos, Sociais e Culturais, f) Convenção Americana de Direitos Humanos, g) Convenção Interamericana para Prevenir, Punir e Erradicar a Violência Contra a Mulher, h) Protocolo à Convenção Americana referente à Abolição da Pena de Morte, i) Estatuto de Roma, j) Protocolo Facultativo à Convenção sobre a Eliminação de todas as Formas de Discriminação contra a Mulher, e a estes avanços normativos, reconheceu-se a jurisdição da Corte Interamericana de Direitos Humanos, em 1998.

${ }_{5}^{5}$ America's Watch, Criminal injustice:violence against women in Brazil (1992).
}

Revista de Direito Brasileira | São Paulo, SP | v. 17 | n. 7 | p. 221 - 244 | Mai./Ago. 2017 
Porém, antes da Convenção de Belém do Pará, o art. $4^{\circ}$-1 da Convenção Internacional sobre a Eliminação de todas as formas de Discriminação contra a Mulher - adotada pela Resolução 34/180 da Assembleia Geral das Nações Unidas em 18 de dezembro de 1979 e ratificada pelo Brasil em 01 de fevereiro de 1984 - prevê: "A adoção pelos Estados-partes de medidas especiais de caráter temporário destinadas a acelerar a igualdade de fato entre o homem e a mulher não se considerará discriminação na forma definida nesta Convenção, mas de nenhuma maneira implicará, como consequência, a manutenção de normas desiguais ou separadas; essas medidas cessarão quando os objetivos de igualdade de oportunidade $e$ tratamento houverem sido alcançados".

No contexto de afirmação dos direitos das mulheres como direitos humanosfundamentais, é válido insistir que a proteção de gênero a partir da esfera privada justifica-se uma vez que esses direitos são princípios que produzem efeitos sobre toda a ordem jurídica, sendo dotados de uma eficácia expansiva que inclui todos os âmbitos jurídicos. Podem ser analisados na dimensão vertical (Estado-cidadão), mas também na horizontal (isto é, na esfera jurídica privada, entre pessoas e entidades não estatais, as quais se encontram em posição de igualdade formal), toda vez que houver desequilíbrio de poderes entre os particulares. Afinal, os direitos humanos-fundamentais não têm como inimigo exclusivo o Estado, na medida em que a violação a tais direitos podem prover também, e às vezes como maior gravidade, dos poderes privados e dos outros particulares (CAMBI, 2016, p. 32-33).

$\mathrm{O}$ art. $6^{\circ}$ da Lei Maria da Penha declara que a violência doméstica e familiar contra a mulher constitui uma das formas de violação dos direitos humanos. Os direitos à vida, à saúde e à integridade física das mulheres são violados quando um membro da família tira vantagem de sua força física ou posição de autoridade para causar maus-tratos físicos, sexuais, morais e psicológicos ${ }^{6}$. Enquanto a violência doméstica não for considerada, não haverá democracia efetiva nem igualdade real. Logo, afirmar a legitimidade das medidas protetivas, contempladas na Lei 11.340/2016, é fomentar mudanças de paradigma cultural em prol da diminuição das diferenças de gênero desde a sua gênese, isto é, o ambiente doméstico e familiar.

\section{LEI MARIA DA PENHA COMO INSTRUMENTO DE AÇÃO AFIRMATIVA}

O caso de Maria da Penha Maia Fernandes é significativo, pois foi a primeira vez que um caso de violência doméstica e familiar levou um país à condenação, por negligência e omissão, no sistema interamericano de proteção dos direitos humanos ${ }^{7}$.

Também marcou o reconhecimento da tese histórica - sustentada pelo movimento e pela criminologia feminista - de que ao contrário do que se sugeria, as violências sentidas pelas mulheres são sofridas majoritariamente em âmbito doméstico, por pessoas que possuem com a vítima proximidade e intimidade.

Aliás, conforme dados divulgados pelo Balanço dos atendimentos realizados em 2015 pela Central de Atendimento à Mulher - Ligue 180 da Secretaria de Políticas para as Mulheres da Presidência da República, 74\% dos relatos de violência registrados é diária ou semanal, sendo que $72 \%$ dos casos as agressões foram cometidas por homens com quem as vítimas mantém ou mantiveram uma relação afetiva. Em quase metade dos registros (49,54\%), o tempo de relacionamento entre a ofendida e o agressor é de mais de 05 (cinco) anos.

A verificação de que as agressões praticadas contra a mulher se dá, majoritariamente, no âmbito privado traz importantes conclusões como a de que o ambiente familiar não é tão seguro nem favorável à proteção das mulheres como deveria ser.

\footnotetext{
${ }^{6}$ Cfr. Item 12 da Exposição de Motivos do Projeto de Lei sobre violência doméstica ou familiar contra a mulher.

7 Caso n. 12.051/Organização dos Estados Americanos. Link para download da decisão em < http://www.sbdp.org.br/arquivos/material/299_Relat\%20n.pdf > Acesso em 27/07/2016.
}

Revista de Direito Brasileira | São Paulo, SP | v. 17 | n. 7 | p. 221 - 244 | Mai./Ago. 2017 
Conforme Pierre Bourdieu, se a unidade doméstica é um dos lugares em que a dominação masculina se manifesta de maneira mais indiscutível (e não só por meio do recurso à violência física), o princípio de perpetuação das relações de força materiais e simbólicas que aí se exercem se colocam essencialmente fora desta unidade, em instâncias como a Igreja, a Escola ou o Estado e em suas ações propriamente políticas, declaradas ou escondidas, oficiais ou oficiosas (BOURDIEU, 2012, p. 138).

Com efeito, a constatação de que os ambientes privado e público se refletem e se perpetuam em instâncias de dominação masculinas permite concluir que a desigualdade entre os gêneros não se traduz apenas no desequilíbrio da representação política entre homens e mulheres, mas também na falta de igualdade na seara privada.

Com isso, não basta a promoção da isonomia nos espaços públicos e políticos. Essa luta por igualdade é necessária, mas não é a única para reduzir a vulnerabilidade e aumentar os direitos das mulheres.

É certo que a isonomia jurídica varia conforme as camadas sociais. Não se pode criar um universalismo fictício, pois os anseios das mulheres pertencentes, sobretudo a "classe média branca acadêmica", são distintos da realidade de grande parte das mulheres negras periféricas, que sofrem com a incidência de fatores socioculturais agravantes de suas condições. Tanto é que o Mapa da Violência 2015 mostra que o número o número de mortes violentas de mulheres negras aumentou 54\% em dez anos, passando de 1.864 casos registrados, em 2003, para 2.875, em 2013, enquanto que a quantidade anual de feminicídios de mulheres brancas caiu em 9,8\%, isto é, de 1.747, em 2003, para 1.576, em 2013. Levar em consideração os diferentes contextos sociais é relevante para diminuir a perpetuação de desigualdades entre os gêneros e a dominação masculina.

A concretização do princípio da igualdade substancial depende de ações políticas, aplicadas ou reguladas pelo Estado, capazes de corrigir as desigualdades mediante a fixação de políticas públicas que estabeleçam discriminações positivas. É, por isso, que a ação afirmativa emergiu como a face construtiva e construtora do novo conteúdo a ser concretizado no princípio da igualdade jurídica (GARCIA, 2009, p. 106-107).

Nesse sentido, a Lei Maria da Penha é um importante instrumento de ação afirmativa, já que possui o objetivo de eliminar desigualdades historicamente acumuladas para assegurar igualdade de tratamento e compensar perdas provocadas pela discriminação e marginalização históricas, decorrente de motivos de gênero.

Isso porque a Lei 11.340/2016 reconhece as violências de gênero a partir do ambiente doméstico, estabelecendo critérios de fomento de igualdade material a partir desse ambiente, com reflexos na esfera pública. Afinal, no Brasil, a violência doméstica praticada contra a mulher resulta de uma sociedade desenvolvida historicamente sobre alicerces patriarcais que legam uma situação de inferioridade fática ainda presente em diversas regiões do país (ROCHA, 1996, p.90).

Tal contexto justifica a adoção de ações afirmativas, de caráter temporário (inclusive para não se instaurar uma discriminação inversa; ou seja, da minoria contra a maioria, o que também seria a negação do princípio da igualdade jurídica) (GOMES, 2001, p. 77-78), voltadas à alteração dos padrões histórico-culturais desiguais e desfavoráveis às mulheres, ainda presentes na sociedade brasileira.

\section{A CONSTITUCIONALIDADE DA LEI MARIA DA PENHA}

A Lei Maria da Penha, contudo, sofreu críticas ao buscar criar ações afirmativas para coibir a violência doméstica e familiar contra a mulher.

É certo que nem sempre leis sobre igualdade de tratamento produzem por si só tratamentos igualitários faticamente, sendo que muitas delas geram uma falsa sensação de isonomia.

Revista de Direito Brasileira | São Paulo, SP | v. 17 | n. 7 | p. 221 - 244 | Mai./Ago. 2017 
A sociedade, apesar das leis protetivas, pode continuar reproduzindo situações de desigualdades, o que permite conduzir à manutenção da hierarquização social quanto às minorias na questão de gênero. Isso reforça a hegemonia cultural dos homens que, por ocupam majoritariamente posições (econômicas, políticas e sociais) superiores, integram o grupo dominante. Tal situação não pode ser justificada como uma ordem natural das coisas para que as leis protetivas possam transformar a realidade social.

A Lei Maria da Penha procurou promover a igualdade constitucional em relação a gêneros para desfazer a visão idealista entre a realidade dos fatos e a lei. A lei não pode presumir uma igualdade sem existência real, criando consequências imprevistas e involuntárias quanto à situação das mulheres. Analisar o direito, na perspectiva feminista, é importante para se diagnosticar as áreas e os problemas a serem enfrentados, para suprimir os vazios jurídicos e buscar dar efetividade aos direitos humanos-fundamentais das mulheres.

Enfrentar questões como a da assistência em âmbito da vida privada e quanto ao trabalho serve para modificar a relação entre a família e o Estado, e contribuir para alterar a distinção entre privado e público (DAHL, 1993, p. 7-9).

A Lei Maria da Penha é um exemplo de discriminação legislativa positiva, pois passa a considerar oficialmente que há efetivamente uma hierarquização e naturalização da condição de hegemonia e superioridade masculina tanto nas esferas públicas de atuação (desde relações laborais a postos políticos) quanto na esfera privada (o ambiente doméstico). Consequentemente, é dever do Estado reconhecer tal diferença e promover ações e políticas públicas de equiparação real de condições de igualdade, ainda que para tanto utilize-se de formatação legal não tradicional, para por meio de um método híbrido proteger com regras de direito de família, penal e processual a esfera doméstica e familiar da mulher.

A própria Constituição da República prevê discriminações em favor das mulheres (em questões previdenciárias e trabalhistas, por exemplo; arts. $7^{\circ}$., inc. XX, 40, inc. III, e $201, \S 7^{\circ}$, CR). Assim, o constituinte incorporou na Lei Fundamental temas relacionados à diferença de gênero para melhor proteger as minorias. Com isso produziu inovações paradigmáticas ao retirar o Direito de seu locus tradicional de mantenedor e reprodutor de relações de poder, para instrumentalizá-lo como efetivo moto-operante das mudanças sociais.

A Lei Maria da Penha não consolida uma visão punitivista da administração da justiça (BIANCHINI, 2016, p.118-119) próxima de movimentos político-criminais maximalistas (a chamada "esquerda punitiva"), porque o rol de medidas de proteção e coibição está em sintonia com o ordenamento jurídico. A utilização de medidas protetivas de urgência capazes de privação da liberdade do ofensor respeitam as garantias previstas pelo Código de Processo Penal referente às medidas acautelatórias, o que demonstra que existe gradação na aplicação de tais medidas, sendo reservadas para os casos mais graves.

Por outro lado, a Lei 11.340/2006 não estabelece novos tipos penais, mas apenas procedimentos diferenciados para as condutas de violência doméstica e familiar contra a mulher, mesmo que tenha criado, no art. 43, agravante de pena no art. 61, inc. II, letra "f", do Código Penal ("com abuso de autoridade ou prevalecendo-se de relações domésticas, de coabitação ou de hospitalidade, ou com violência contra a mulher na forma de lei especifica”).

Portanto, os atos de violência contra as mulheres, em sua maioria, podem ser traduzidos no que o direito penal e a criminologia caracterizam como criminalidade tradicional, ou seja, tais condutas implicam danos concretos, praticados por e contra "pessoas de carne e osso", em que são afetados bens jurídicos tangíveis, palpáveis, como vida, integridade física e liberdade sexual. Logo, diferentemente do que é projetado atualmente como política criminal punitivista, a Lei Maria da Penha não inova ao não ampliar as hipóteses de criminalização ${ }^{8}$. Desse modo, a mera

${ }^{8}$ Conforme Marilia Montenegro, o "Direito Penal ignora por completo a violência estrutural e os seus condicionamentos, pois o seu discurso é simplesmente punitivo, procurando apenas atribuir culpa a alguém (...). Termina, portanto, estigmatizando os sujeitos envolvidos, oferecendo falsas soluções e, não satisfazendo a vítima,

Revista de Direito Brasileira | São Paulo, SP | v. 17 | n. 7 | p. 221 - 244 | Mai./Ago. 2017 
especificação da violência de gênero para hipóteses de condutas criminalizadas já existentes não produz o aumento da repressão penal, sendo compatível inclusive com pautas político-criminais minimalistas ${ }^{9}$.

Afastado o rótulo punitivista da Lei Maria da Penha, é preciso reforçar a sua condição de instrumento de ação afirmativa ao reconhecer a hipossuficiência de gênero em relações domésticas e familiares como reflexo cultural de uma sociedade historicamente androcêntrica, opressora, discriminatória e inferiorizante em relação às mulheres, com implicações tanto na esfera privada quanto na pública de convívio. Desse modo, as desigualdades de gênero entre homem e mulher não encontram respaldo nas diferenças biológicas dadas pela natureza, mas advém de uma construção sociocultural, que passa a considerar natural uma desigualdade socialmente construída, que admite atos de discriminação e violência contra mulheres e transforma o ambiente privado em espaços de complacência e impunidade ${ }^{10}$. Tal compreensão ajuda combater certos mitos como o de que "em briga de marido e mulher ninguém mete a colher", que acaba por reproduzir estereótipos de gênero que, ao enaltecer a "harmonia familiar", torna menos visível a violência contra a mulher (MORATO; SANTOS; RAMOS; LIMA, 2009, p. 92). Nesse contexto social, a Lei 11.340/2006 prevê um conjunto de medidas compensatórias, que, mediante discriminações positivas, podem provocar equiparações equitativas entre os seres humanos.

Assim, a Lei Maria da Penha prevê, por exemplo, à aplicação concomitante de medidas de urgência protetivas (o que resolve a necessidade imediata da mulher em situação de violência; arts. 18 a 24), a implementação de políticas públicas para garantia dos direitos humanos das mulheres (art. $3^{\circ}, \S \S 1^{\circ}$ e $2^{\circ}$ ), além de uma orientação interpretativa aos intérpretes da lei que deve considerar os fins sociais e, especificamente, as condições peculiares das mulheres em situação de violência doméstica e familiar (art. $4^{\circ}$ ).

As críticas contra a Lei Maria da Penha não resistem a um exame mais profundo da própria lei e da consideração do Direito como efetivo meio de transformação social, como utopia democratizante de conquistas de inclusão social de minorias historicamente alijadas do processo político $^{11}$.

Por votação unânime, o Plenário do Supremo Tribunal Federal declarou, na ADC 19, a constitucionalidade dos arts. $1^{\circ}, 33$ e 41 da Lei 11.340/2006 (Lei Maria da Penha) ${ }^{12}$. Vale destacar o voto do Ministro Ayres Britto, ao dizer que a lei está em consonância plena com a Constituição Federal (art. 226, $\S 8^{\circ}$ ), podendo ser enquadrada no que denominou de "constitucionalismo fraterno" ao prever proteção especial à mulher: "A Lei Maria da Penha é mecanismo de concreção da tutela especial conferida pela Constituição à mulher. E deve ser interpretada generosamente para robustecer os comandos constitucionais”.

que, muitas vezes, pode deixar a Justiça com o rótulo de que 'gosta de apanhar'. (...) não será através do Direito Penal que a mulher encontrará a proteção e a igualdade, pois a mudança de comportamento e de mentalidade vem através da educação e de ações preventivas" (Lei Maria da Penha: uma análise criminológico-crítica. Rio de Janeiro: Revan, 2015. p. 197-198).

${ }^{9}$ Cfr. Item 16 da Exposição de Motivos do Projeto de Lei sobre violência doméstica ou familiar contra a mulher.

${ }^{10}$ MORATO, Alessandra Campos; SANTOS, Claudiene; RAMOS, Maria Eveline Cascardo; LIMA, Suzana Canaez da Cruz. Análise da relação sistema de justiça criminal e violência doméstica contra a mulher. Brasília: ESMPU, 2009. p. 92.

${ }^{11}$ Quanto à mudança de paradigma ao constituir a democracia como direito fundamental, e perceber o Estado como novíssimo movimento social apto a efetivar a inclusão de minorias por meio do direito e de participação popular radical, conferir: ALVES, Fernando de Brito. Para uma fundamentação dos direitos de minorias em tempos de transição paradigmática. Dissertação de mestrado (ciências jurídicas). Jacarezinho: Universidade Estadual do Norte do Paraná, 2009.Constituição e participação popular: a construção histórico-discursiva do conteúdo jurídicopolítico da democracia como direito fundamental. Curitiba: Juruá, 2013.

12 ADC 19, Relator(a): Min. MARCO AURÉLIO, Tribunal Pleno, julgado em 09/02/2012, ACÓRDÃO ELETRÔNICO DJe-080 DIVULG 28-04-2014 PUBLIC 29-04-2014.

Revista de Direito Brasileira | São Paulo, SP | v. 17 | n. 7 | p. 221 - 244 | Mai./Ago. 2017 
A Constituição de 1988, ao definir o Estado brasileiro como um Estado Democrático de Direito, orienta a produção de uma ordem jurídica justa, estabelecendo já no seu Prefácio que os constituintes se reuniram para "instituir um Estado Democrático, destinado a assegurar o exercício dos direitos sociais e individuais, a liberdade, a segurança, o bem-estar, o desenvolvimento, a igualdade e a justiça como valores supremos de uma sociedade fraterna, na ordem interna e internacional (...)”. Logo, a igualdade é um ideal a ser alcançado, pois a sociedade brasileira somente será considerada justa se os cidadãos forem considerados iguais, $o$ que exige não apenas a correta aplicação do direito, mas também a adoção de critérios justos na construção normativa e institucional (CLÈVE, 2015, p. 25-26).

Nesse sentido, não há dúvidas que a Lei 11.340/2006 é constitucional, ao assegurar às mulheres em condição de vulnerabilidade um sistema protetivo que, por meio da tutela diferenciada, pode contribuir para viabilizar ações positivas que favoreçam as minorias e reduzam as desigualdades existentes (CORRÊA, 2011, p. 14-18).

\section{TUTELA DIFERENCIADA NA LEI MARIA DA PENHA}

A Lei Maria da Penha preocupou-se em tutelar adequadamente a violência doméstica e familiar contra as mulheres, prevendo medidas de inserção, de prevenção, de proteção e de coibição (GARCIA, 2009, p. 103). Aliás, o art. $1^{\circ}$ da Lei 11.340/2006 explica que tal legislação cria mecanismos para coibir e prevenir a violência doméstica e familiar contra a mulher, nos termos do $8^{\circ}$ do art. 226 da Constituição Federal, da Convenção sobre a Eliminação de Todas as Formas de Violência contra a Mulher, da Convenção Interamericana para Prevenir, Punir e Erradicar a Violência contra a Mulher e de outros tratados internacionais ratificados pela República Federativa do Brasil; dispõe sobre a criação dos Juizados de Violência Doméstica e Familiar contra a Mulher; e estabelece medidas de assistência e proteção às mulheres em situação de violência doméstica e familiar.

Destaca-se, de início, a preocupação terminológica, pois a Lei Maria da Penha não rotula a mulher que está em situação de violência doméstica como vítima, até mesmo para não revitimizá-la. Refere-se, pois, às “mulheres em situação de violência doméstica".

Trata-se de relevante recurso linguístico, preocupado em retirar o estigma contido na categoria "vítima". Com isso, superam-se as classificações do direito penal clássico, posto que a expressão escolhida ("mulheres em situação de violência doméstica") indica a recuperação da condição de sujeito de direitos da mulher, como circunstância provisória e não definidora de si, em condição transitória e a superar a situação de violência vivida. A expressão "vítima" reduzia ou mesmo anularia a autonomia dessas mulheres (CAMPOS; CARVALHO, 2011, p. 146).

Ademais, a Lei Maria da Penha cuida da violência doméstica como violência de gênero, não de sexo. Tal diferenciação quanto aos termos também é relevante sobretudo quanto ao processo interpretativo a fim de buscar atingir os fins sociais a que a Lei 11.340/2016 visa cumprir, em especial as condições peculiares das mulheres em situação de violência doméstica e familiar (art. $\left.4^{\circ}\right)$.

O conceito de sexo decorre de uma determinação biológica (sexo feminino e sexo masculino em referência aos órgãos reprodutivos), enquanto a categoria gênero resulta de uma construção cultural. $\mathrm{O}$ argumento cultural de gênero é relacional, conjugando a dominação do masculino e a submissão do feminino. Essa assimetria de poder implica a fórmula de prepotência do masculino somada à subalternidade do feminino.

Nessa perspectiva, a Lei 11.340/2016 procura influir na ordem simbólica para redefinir as relações de poder. Por isso, prevê-se mecanismos especiais de proteção, como a criação de Juizados de Violência Doméstica e Familiar contra a Mulher, com competência Cível e Criminal (arts. $1^{\circ}$., 14-15, 29, 33 e 34), além de atendimento policial especializado para as mulheres nas Delegacias das Mulheres (arts. $8^{\circ}$., inc. IV, e 35, inc. III). 
A Lei Maria da Penha, contudo, não protege apenas a mulher agredida por um homem, aplicando-se também à companheira em relações homoafetivas. Tanto é que o art. $5^{\circ}$ afirma que "as relações pessoais enunciadas neste artigo independem de orientação sexual". Logo, a Lei 11.340/2016 trata da violência doméstica enquanto gênero, expressando seu viés protetivo pelo aspecto cultural de relação de dominação a partir da consideração inferiorizante do feminino, não com fundamento no sexo. Isso permite a incidência da Lei Maria da Penha a qualquer mulher, sem distinção de orientação sexual, vindo a alcançar também lésbicas, travestis, transexuais e/ou transgêneros, independentemente de cirurgia de transgenitalização, alteração do nome ou sexo no documento civil, que mantém relação íntima de afeto em ambiente familiar ou de convívio ${ }^{13}$.

Dessa forma, a Lei Maria da Penha deve ser aplicada a casais homoafetivos, quando o âmago do conflito de violência é reflexo da dominação irregular e desigual baseada em subjugamento, submissão, dominação e assimetria de poder. Tal conclusão permite o processamento da mulher companheira, por reprodução da mesma lógica de violência de gênero em circunstância que legitima a intervenção protetiva. Porém, a incidência da Lei 11.340/2016 depende da verificação, no caso concreto, da existência de motivação de gênero e da comprovação da relação doméstica, familiar ou de afetividade, ainda que eventuais e/ou efêmeras ${ }^{14}$, como fatores determinantes da prática da violência ${ }^{15}$. Presentes esses requisitos, a Lei 11.340/2006 se aplica às uniões homossexuais entre mulheres, para, por exemplo, possibilitar o afastamento do lar da agressora (art. 22, inc. II), a restrição de visitas ao filho adotado (em analogia ao art. 22, inc. IV) e a fixação de alimentos (art. 22, inc. V) (CUNHA; PINTO, 2015, p. 75).

A Lei Maria da Penha, também, reconhece a urgência da interferência do Estado, em razão da situação de vulnerabilidade. Assim, a repressão criminal não é suficiente para prevenir um conjunto de atos e manifestações culturais refletidoras de dominação. Por isso, o art. $8^{\circ}$, inc. I, da Lei 11.340/2006 estabelece medidas integradas de prevenção, ao assentar que a política

\footnotetext{
${ }^{13}$ DIAS, Maria Berenice. Violência doméstica e as uniões homoafetivas. Revista Jus Navigandi, Teresina, ano 11, n. 1185, 29 set. 2006. Disponível em: <https://jus.com.br/artigos/8985>. Acesso em:1 set. 2016. Nesse sentido, conferir, ainda, o Enunciado ${ }^{\circ} 30$ do Conselho Permanente de Violência Doméstica e Familiar (COPEVID) do Grupo Nacional de Defesa dos Direitos Humanos (GNDH), vinculado ao Conselho Nacional de Procuradores Gerais de Justiça do Ministério Público dos Estados e da União.

${ }^{14}$ A propósito, verificar o Enunciado no 21 do Conselho Permanente de Violência Doméstica e Familiar (COPEVID) do Grupo Nacional de Defesa dos Direitos Humanos (GNDH), vinculado ao Conselho Nacional de Procuradores Gerais de Justiça do Ministério Público dos Estados e da União.

15 "RECURSO EM SENTIDO ESTRITO. VIOLENNCIA DOMÉSTICA. UNIÃO HOMOAFETIVA. POSSIBILIDADE. ANÁLISE DO CASO CONCRETO. RELAÇÃO ÍNTIMA PRETÉRITA. AUSÊNCIA DE PERTINÊNCIA. MOTIVAÇÃO DESVINCULADA DO GÊNERO. INEXISTÊNCIA DE CONDIÇÃO DE HIPOSSUFICIÊNCIA OU VULNERABILIDADE. INAPLICABILIDADE DA LEI MARIA DA PENHA. DECISÃO MANTIDA. RECURSO DESPROVIDO. 1. Os dispositivos da Lei Maria da Penha são também aplicáveis às mulheres que, no uso de sua liberdade sexual, mantêm relacionamentos homoafetivos. É dizer: a lei não desampara a mulher pelo fato de sua relação íntima estabelecer-se com pessoa do mesmo sexo, sendo certo que conclusão diversa seria absolutamente inconstitucional. 2. A Lei Maria da Penha define com clareza o sujeito passivo da violência doméstica, que será sempre a mulher. Contudo, o sujeito ativo poderá ser tanto o homem quanto a mulher, devendo a análise do caso concreto atentar-se à existência ou não de motivação de gênero e utilização da relação doméstica, familiar ou de afetividade como escopo para a prática da violência, fatores que serão determinantes para concluir-se pela (in)aplicabilidade da referida norma. 3. Não se verifica a permanência de qualquer vínculo íntimo entre a ofendida e a recorrida: o transcurso de significativo lapso temporal entre o término do relacionamento (2008) e a data da suposta ameaça (2013), bem como a prova da existência de sério relacionamento afetivo posterior, obstam eventual presunção de que a violência tenha sido decorrente da relação de afeto mantida, no passado, entre a vítima e a agressora. 4. A motivação da suposta ameaça teria sido um desentendimento entre agressora e ofendida, fundado no receio por parte da agressora de que a vítima estivesse colaborando para que os credores encontrassem o seu endereço, motivo que não guarda qualquer pertinência com a relação homoafetiva mantida e encerrada anos atrás. 5. Não se constata que a vítima estivesse em condição de vulnerabilidade ou hipossuficiência frente à recorrida. 6 . Recurso desprovido" (TJ/DF - 2a Turma Criminal - rel. Silvânio Barbosa dos Santos - j. 03.04.2014 - pub. DJE 09.04.2014, p. 386).
}

Revista de Direito Brasileira | São Paulo, SP | v. 17 | n. 7 | p. 221 - 244 | Mai./Ago. 2017 
pública que visa coibir a violência doméstica e familiar contra a mulher far-se-á por meio de um conjunto articulado e multidisciplinar de ações da União, dos Estados, do Distrito Federal e dos Municípios e de ações não-governamentais, tendo como uma das diretrizes a integração operacional do Poder Judiciário, do Ministério Público e da Defensoria Pública com as áreas de segurança pública, assistência social, saúde, educação, trabalho e habitação.

Para que a proteção de mulheres que sofrem violência doméstica e familiar seja mais eficiente, o art. 41 da Lei 11.340/2006 exclui a aplicação da Lei 9.099/95, independentemente da pena prevista aos crimes praticados. Tal exclusão ocorre porque os Juizados Especiais da Lei 9.099/95, apesar de terem sido criados para desafogar a justiça brasileira e evitar a estigmatização do sistema penal, não foram pensados a partir das relações de gênero, mas para punir condutas criminosas masculinas, tendo como consequências: i) a banalização da violência doméstica; ii) a ausência de proteção integral das mulheres ofendidas; iii) o arquivamento sistemático de autos ou a absolvição do autor do fato pela conduta omissiva da vítima em responsabilizar o autor da violência (ao não registrar boletins de ocorrência ou, após registrá-lo, renunciando ao direito de representação ou até com a retratação em juízo para inocentar o agressor) (CAVALCANTI, 2012, p. 193-194) (FERNANDES, 2015, p. 124-134).

$\mathrm{O}$ art. 41 da Lei 11.340/2006 evita, destarte, que delitos como os de ameaça ou de lesões corporais leves, praticados no ambiente doméstico e familiar, sejam processados pelo procedimento sumaríssimo da Lei 9.099/1995, o que retira a possibilidade deles serem tratados como infrações de menor potencial ofensivo. A aplicação da Lei 9.099/95, para a violência doméstica e familiar, acabaria por ignorar as características dessa violência, tal como o grau de comprometimento emocional que as mulheres são submetidas em relação ao comportamento ilícito, reiterado e cotidiano do agressor, a assimetria de forças, o medo, a vergonha, o sentimento de culpa pelo fracasso das relações familiares, a crença na mudança do parceiro, a inversão da culpa, a revitimização da mulher em decorrência do precário atendimento e das posturas inadequadas das autoridades públicas, o medo de reviver o trauma, a violência sexual, o cárcere privado e a escalada da violência (afinal, as mulheres ofendidas, não raro, passam por várias tentativas de separação, agressões e ameaças, idas e vindas a Delegacia de Polícia, sendo que muitas delas, infelizmente, culminam em feminicídio ou suicídio) (CAVALCANTI, 2012, p. 195) (FERNANDES, 2015, p. 124-134). Como consequência, a incidência da Lei 9.099/95 tornaria a proposta despenalizante positiva para o autor do fato, mas negativa na perspectiva da ofendida, pois àquele poderia ser beneficiado com a transação penal (art. 76) ou com a suspensão do processo (art. 89). Por tudo isso, a violência doméstica e familiar contra a mulher exige cuidado legislativo diferenciado capaz de promover todos os seus direitos fundamentais inerentes à condição de pessoa humana (art. $2^{\circ}$ da Lei 11.340/2006), não podendo ser objeto do mesmo tratamento dispensado às infrações de menor potencial ofensivo da Lei 9.099/95.

Atento a essa diferenciação, o Supremo Tribunal Federal, na ADC 19, declarou a constitucionalidade do art. 41 da Lei 11.340/2006, por estar em consonância com o disposto no $\S$ $8^{\circ}$ do art. 226 da Carta da República, que prevê a obrigatoriedade de o Estado adotar mecanismos que coíbam a violência no âmbito das relações domésticas e familiares ${ }^{16}$. Por sua vez, o Superior Tribunal de Justiça editou a Súmula 536, com a seguinte redação: “A suspensão condicional do processo e a transação penal não se aplicam na hipótese de delitos sujeitos ao rito da Lei Maria da Penha". De igual modo, a jurisprudência do STJ caminha para não admitir a aplicação do princípio da insignificância no que se refere aos crimes praticados com violência ou grave ameaça contra mulher, no âmbito das relações domésticas ${ }^{17}$.

16 ADC 19, Relator(a): Min. MARCO AURÉLIO, Tribunal Pleno, julgado em 09/02/2012, ACÓRDÃO ELETRÔNICO DJe-080 DIVULG 28-04-2014 PUBLIC 29-04-2014.

${ }^{17}$ REsp 1537749/DF, Rel. Ministro ROGERIO SCHIETTI CRUZ, SEXTA TURMA, julgado em 30/06/2015, DJe 04/08/2015.

Revista de Direito Brasileira | São Paulo, SP | v. 17 | n. 7 | p. 221 - 244 | Mai./Ago. 2017 
Em complementação ao art. 41 da Lei 11.340/2006, o art. 17 da Lei Maria da Penha veda, expressamente, nos casos de violência doméstica e familiar contra a mulher, a aplicação de penas de cesta básica ou de prestação pecuniária, bem como a substituição de pena que implique o pagamento isolado de multa.

Com efeito, fica prejudicado, no âmbito da violência doméstica contra a mulher, a incidência do art. 44, inc. I, do Código Penal, que permite a substituição de pena privativa de liberdade por restritivas de direito, na forma de prestação pecuniária (art. 43, inc. I, CP), a crime sem violência ou grave ameaça, cuja pena não seja superior a quatro anos, ou, qualquer que seja a pena aplica, se o crime for culposo ${ }^{18}$.

A Lei 11.340/2006 inova ao prever a concessão pelo Estado-juiz de medidas protetivas de urgência que podem obrigar o agressor (art. 22), beneficiar diretamente a ofendida (art. 23) ou salvaguardar os bens comuns ou próprios da mulher (art. 24). Além dessas medidas provisionais típicas, há a possibilidade da concessão de outras medidas previstas na legislação em vigor (podendo-se deduzir da leitura do caput dos arts. 22, 23 e 24 o princípio da atipicidade das medidas protetivas de urgência), inclusive com a possibilidade de aplicação, no que couber, dos arts. 536 e 537, $\S 1^{\circ}$, do NCPC (art. 22, $\S 1^{\circ}$ e $4^{\circ}$ da Lei Maria da Penha), que permite a concessão de tutela específica dos deveres de fazer, não fazer e dar coisa distinta de dinheiro, a partir da análise pelo juiz da medida mais adequada, necessária e proporcional para alcançar o melhor resultado no caso concreto (DIDIER; OLIVEIRA, 2008, p.20).

Consequentemente, ainda que a ofendida ou o Ministério Público tenham requerido determinada medida protetiva (art. 19, $\S 3^{\circ}$, da Lei 11.340/2006) poderá o juiz, por força do art. 22, $\S 4^{\circ}$, da Lei Maria da Penha, que permite a aplicação do art. 536, caput, do NCPC determinar a imposição de medida de urgência diversa da pleiteada. $\mathrm{O}$ magistrado pode assim agir, mesmo de ofício, quando, em decisão fundamentada, entender que medida protetiva diversa da requerida é mais adequada e eficiente para a proteção do bem jurídico a ser tutelado ${ }^{19}$. Nesta situação, como é o próprio ordenamento jurídico quem autoriza o juiz a implementar a medida mais adequada para tornar efetiva a tutela almejada, não há violação da regra da congruência, que impede o juiz de proferir decisão de natureza diversa da pedida (art. 492 do CPC).

Assim, por exemplo, é possível que o juiz, junto com as medidas protetivas de urgência, busque convencer os envolvidos no litígio a participarem de processos restaurativos (PORTO, 2014, p. 141), com o intuito de promover a responsabilização dos ofensores, proteção às vítimas, bem como restauração e estabilização das relações familiares, conforme o art. 24 da Resolução $\mathrm{n}^{\circ}$ 225/2016 do Conselho Nacional de Justiça, que dispõe sobre a Política Nacional de Justiça Restaurativa no âmbito do Poder Judiciário, o qual acresceu o $\S 3^{\circ}$ ao art. $3^{\circ}$ da Resolução $n^{\circ}$ 128/2011 do CNJ, sobre a criação de Coordenadorias Estaduais das Mulheres em Situação de Violência Doméstica e Familiar no âmbito dos Tribunais de Justiça.

As medidas protetivas de urgência também podem ser substituídas a qualquer tempo por outras de maior eficácia, sempre que os direitos previstos na Lei Maria da Penha forem ameaçados ou violados (art. 19, § $3^{\circ}$, da Lei 11.340/2006).

Não obstante o art. 12, inc. III, da Lei 11.340/2006 afirme que cabe a autoridade policial, nos casos de violência doméstica e familiar contra a mulher, após o registro da ocorrência, sem prejuízo das medidas previstas no Código de Processo Penal, remeter, no prazo de 48 (quarenta e oito) horas, expediente apartado ao juiz com o pedido da ofendida, para a concessão de medidas protetivas de urgência, o alcance de proteção da Lei Maria da Penha não se limita ao âmbito do Direito Penal ou do Processual Penal.

\footnotetext{
${ }^{18}$ STJ, REsp 1593430/RJ, Rel. Ministro SEBASTIÃO REIS JÚNIOR, SEXTA TURMA, julgado em 24/05/2016, DJe 13/06/2016.

${ }^{19}$ STJ, AgRg no AREsp 239.675/ES, Rel. Ministro RAUL ARAÚJO, QUARTA TURMA, julgado em 05/02/2015, DJe 24/02/2015.
} 
A violência doméstica e familiar também pode repercutir na esfera cível, gerando efeitos como os da definição da obrigação de perdas e danos ou do pagamento de alimentos, da separação do casal, do dever de guarda dos filhos e da proteção patrimonial dos bens da sociedade conjugal ou de propriedade particular da mulher. Tanto é que as medidas protetivas de urgência previstas nos arts. 22, incs. II (afastamento do lar, domicílio ou local de convivência da ofendida), IV (restrição ou suspensão de visitas aos dependentes menores, ouvida a equipe de atendimento multidisciplinar ou serviço similar) e $\mathrm{V}$ (prestação de alimentos provisionais ou provisórios), 23, incs. III (afastamento da ofendida do lar, sem prejuízo dos direitos relativos a bens, guarda dos filhos e alimentos) e IV (separação de corpos) e 24 (restituição de bens indevidamente subtraídos pelo agressor à ofendida; proibição temporária para a celebração de atos e contratos de compra, venda e locação de propriedade em comum, salvo expressa autorização judicial; suspensão das procurações conferidas pela ofendida ao agressor; e prestação de caução provisória, mediante depósito judicial, por perdas e danos materiais decorrentes da prática de violência doméstica e familiar contra a ofendida) possuem natureza cível.

Aliás, diversas medidas protetivas previstas nos arts. 22, 23 e 24 da Lei 11.340/2006 foram retiradas do Código de Processo Civil de 1973, como o afastamento temporário de um dos cônjuges da morada do casal (art. 888, inc. VI, CPC/73, reproduzido no art. 22, inc. II, da Lei Maria da Penha) ou a concessão de alimentos provisionais (art. 852 do CPC/73, contida no art. 22, inc. V, da Lei Maria da Penha). O Novo Código de Processo Civil não prevê, exaustivamente, a regulamentação de medidas cautelares, limitando-se a consagrar no art. 301 o direito geral à tutela de urgência de natureza cautelar.

O princípio da atipicidade das medidas protetivas de urgência, adotado no caput dos arts. 22, 23 e 24 da Lei 11.340/2006, aliada a expressa remissão ao Código de Processo Civil, no art. $22, \S 4^{\circ}$, permitem a conjugação dos sistemas processuais a possibilitar que os avanços trazidos pelo NCPC também beneficiem às mulheres em situação de violência doméstica e familiar. Assim, não apenas as tutelas de urgência de natureza cautelar (art. 301 do NCPC), mas também as técnicas inerentes às tutelas antecipada, de evidência, inibitória e da remoção do ilícito podem servir para assegurar às mulheres as condições para o exercício efetivo dos direitos à vida, à segurança, à saúde, à alimentação, à educação, à cultura, à moradia, ao acesso à justiça, ao esporte, ao lazer, ao trabalho, à cidadania, à liberdade, à dignidade, ao respeito e à convivência familiar (art. $3^{\circ}$, caput, da Lei 11.340/2006). Afinal, o fim social da Lei Maria da Penha é tutelar, de forma adequada e eficiente, os direitos das mulheres em situação de violência doméstica e familiar (art. $4^{\circ}$ ), o que não dispensa a utilização das técnicas processuais mais eficientes para a sua integral proteção jurídica. Além disso, o art. 13 da Lei 11.340/2006 não deixa dúvida que aos processos de natureza civil decorrentes de violência doméstica ou familiar contra a mulher devem ser aplicadas as normas do Código de Processo Civil que não conflitarem com o estabelecido na Lei Maria da Penha. A interpretação sistemática dos arts. $4^{\circ}$ e 13 da Lei 11.340/2006 permitem a construção do princípio da máxima efetividade processual para a tutela das mulheres em situação de violência doméstica e familiar.

Nesse contexto, é importante, por exemplo, a aplicação do art. 497, P.Ú., do NCPC, que consagra importante técnica processual preventiva, estabelecendo que para a concessão da tutela específica destinada a inibir a prática, a reiteração ou a continuação de um ilícito, ou a sua remoção, é irrelevante a ocorrência de dano ou a existência de culpa ou dolo (MARINONI; in CAMBI \& MARGRAF, 2016, p.681). Com isso, o NCPC promove técnicas processuais diferenciadas para a superação do princípio da igualdade formal, baseado na exclusividade da tutela ressarcitória pelo equivalente pecuniário, e, com isso, confere tratamento diferenciado a diferentes necessidades e espécies de bens jurídicos, inclusive para a proteção de posições sociais mais vulneráveis, em especial envolvendo a tutela dos direitos das minorias.

$\mathrm{O}$ art. 497, P.Ú., do NCPC possibilita a concessão tanto da tutela inibitória, que pode ser voltada contra a prática, a repetição ou a continuação de um ilícito, quanto da tutela de remoção 
do ilícito, direcionada à remoção dos efeitos concretos da conduta ilícita. Assim, qualquer ato contrário ao direito, independente da produção de danos, pode ser objeto de tutela jurisdicional (v.g., o Estado-Juiz pode impor ao agressor deveres de fazer, não fazer ou entregar coisa para proteger especificamente o resultado pretendido pela ofendida). Por exemplo, o magistrado pode determinar o encaminhamento do agressor a programas de reabilitação para dependentes químicos ou para orientação psicológica.

A propósito, deve ser ressaltado os Enunciados no 9, 19 e 20 do Conselho Permanente de Violência Doméstica e Familiar (COPEVID) do Grupo Nacional de Defesa dos Direitos Humanos (GNDH), vinculado ao Conselho Nacional de Procuradores Gerais de Justiça do Ministério Público dos Estados e da União: "Em sede de medidas de proteção é possível o encaminhamento e a inclusão do agressor usuário dependente de drogas lícitas ou ilícitas em programa oficial ou comunitário de auxílio, orientação e tratamento"; "Os programas de reeducação do agressor, a exemplo dos grupos reflexivos e centros de educação e reabilitação, fazem parte das políticas integradas de proteção às mulheres"; "Dentre outras medidas protetivas de urgência que obrigam o agressor previstas no artigo 22 da Lei Maria da Penha, é possivel a determinação de comparecimento obrigatório a programas de reeducação ou grupos reflexivos". Também nesse sentido é o disposto no art. 16.1 da Convenção da Europa para a Prevenção e o Combate à Violência Doméstica (Convenção de Istambul), de 2011.

Os arts. 14 e 15 da Lei 11.340/2006 definem que os Juizados de Violência Doméstica contra a Mulher para processamento e julgamento das causas cíveis e criminais decorrentes de prática de violência doméstica e familiar contra a mulher. A amplitude da competência conferida pela Lei 11.340/2006 à Vara Especializada teve como objetivo facilitar o acesso da mulher, vítima de violência familiar e doméstica, ao Poder Judiciário, com o intuito de conferir-lhe real proteção, ao permitir que um único magistrado tenha conhecimento das diversas ações cíveis e criminais advindas direta ou indiretamente dos mesmos fatos ${ }^{20}$. Todavia, enquanto não forem estruturados os Juizados de Violência Doméstica e Familiar contra a Mulher, as varas criminais devem acumular as competências cíveis e criminais para conhecer e julgar as causas decorrentes da prática de violência doméstica e familiar contra a mulher (art. 33, caput, da Lei 11.340/2006).

São competentes, por opção da ofendida, para os processos civis, o Juizado de seu domicílio ou de sua residência, do lugar do fato em que se baseou a demanda ou do domicílio do agressor. São hipóteses de competência territorial e, portanto, relativa, isto é, disponível, podendo a demandante escolher o foro que melhor contemple seu interesse de acesso à justiça.

A mulher ofendida possui capacidade postulatória para requerer as medidas protetivas de urgência, não sendo necessário que o pedido seja formulado por advogado, defensor público ou pelo Ministério Público (art. 27 da Lei Maria da Penha) ${ }^{21}$. Entretanto, após a análise da concessão da liminar, o magistrado deve encaminhar a ofendida ao órgão de assistência judiciária para determinar a integração da capacidade postulatória da autora (art. 18, inc. II, da Lei 11.340/2006).

As medidas protetivas de urgência - não obstante o disposto no art. 12, inc. III, da Lei 11.340/2006 - não dependem de boletim de ocorrência ou de representação criminal, podendo ser deferidas paralelamente à abertura de inquérito policial ou do ajuizamento de ação penal. Com isso, também se respeita a autonomia da mulher em situação de violência, porque, ainda que nesses casos ela esteja vulnerável e possa precisar de proteção especial do Estado, não se pode constranger que a mulher, que não deseja registrar boletim de ocorrência ou representar criminalmente o agressor (seja porque possui com ele relação de dependência emocional ou por temor de que ele seja condenado criminalmente) a fazê-lo como condição para a obtenção da

\footnotetext{
${ }^{20}$ STJ, REsp 1496030/MT, Rel. Ministro MARCO AURÉLIO BELLIZZE, TERCEIRA TURMA, julgado em 06/10/2015, DJe 19/10/2015.

${ }^{21}$ DIDIER JÚNIOR, Fredie; OLIVEIRA, Rafael. Aspectos processuais civis da Lei Maria da Penha (Violência doméstica e familiar contra a mulher). Cit. p. 18.
}

Revista de Direito Brasileira | São Paulo, SP | v. 17 | n. 7 | p. 221 - 244 | Mai./Ago. 2017 
tutela protetiva de urgência ${ }^{22}$. Afinal, a determinação judicial de afastamento do agressor do domicílio pode, por si só, conferir à mulher em situação de violência a sensação de segurança e proteção necessárias à manutenção de sua integridade física e psíquica e de seus familiares.

Em contrapartida, quando a medida protetiva de urgência possui caráter penal (como a suspensão da posse ou restrição do porte de armas ou a proibição de determinadas condutas, entre as quais a aproximação ou o contato com a ofendida, de seus familiares e as testemunhas ou a frequentação de determinados lugares a preservar a integridade física e psicológica da ofendida; art. 22, incs. I e III ${ }^{23}$, da Lei 11.304/2006), deve ser aplicado o procedimento previsto no Código de Processo Penal ${ }^{24}$.

Para a concessão da medida protetiva de urgência, a palavra da ofendida serve como indício de autoria da prática da violência doméstica e familiar, porquanto tais atos são praticados, não raro, no âmbito da convivência íntima. Além disso, relatos de reiteradas agressões e ameaças anteriores podem evidenciar risco à integridade física, psicológica, sexual, patrimonial ou moral da ofendida a justificar a imposição das medidas protetivas de urgência ${ }^{25}$.

O princípio da atipicidade das escolhas das medidas protetivas de urgência se estende para os meios executivos apropriados para a imposição da tutela mais adequada, necessária e proporcional. Isso porque os arts. 536 e $537, \S 1^{\circ}$, do $\mathrm{NCPC}$, que correspondem às regras contidas no art. $461, \S \S 5^{\circ}$ e $6^{\circ}$ do CPC-73, aliado ao art. 139, inc. IV, do NCPC, estabelecem uma cláusula geral executiva como resposta ao direito ao meio executivo adequado, na qual está previsto um elenco exemplificativo de medidas executivas a serem adotadas pelo juiz que, após a análise do caso concreto, pode escolher a providência que melhor efetiva a medida protetiva de urgência necessária à proteção da situação de violência doméstica e familiar (MARINONI, 2005 p. 54-74) (DIDIER; OLIVEIRA, p. 22). Logo, havendo o descumprimento dessas medidas, o juiz poderá, de ofício ou a requerimento da parte, determinar as medidas necessárias para a satisfação da ofendida, podendo, dentre outras medidas, ordenar a imposição de multa, a busca e apreensão, a remoção de pessoas ou de coisas, o desfazimento de obras e o impedimento de atividade nociva, pedindo, se necessário, auxílio de força policial (art. 536, $\S 1^{\circ}, \mathrm{NCPC}^{26}$. A medida de coerção pode ser direta (v.g., a busca e apreensão de arma em posse do agressor) ou indireta (v.g., a imposição de multa diária, em valor suficiente para que sirva de estímulo para o cumprimento da ordem judicial, para o caso de não afastamento do lar ou a frequentação de programa de reabilitação para dependentes químicos como condição para o exercício do direito de visita aos dependentes menores).

Entretanto, o não cumprimento da ordem judicial, apesar da orientação jurisprudencial ainda não pacificada pelo Superior Tribunal de Justiça, deve ensejar a prisão em flagrante do ofensor pelo crime de desobediência (art. 330 do Código Penal) ou de desobediência à decisão

\footnotetext{
${ }^{22}$ MONTE, Nalida Coelho. As medidas protetivas de urgência da Lei 11.340/06 não exigem, para sua concessão e manutenção, a existência de boletim de ocorrência, representação criminal ou procedimento criminal. Disponível em: $<$

http://http://www.defensoria.sp.def.br/dpesp/Conteudos/Materia/MateriaMostra.aspx?idItem=65891\&idModulo=970 6\#_ftn7>. Acesso em 30/08/2016.

${ }^{23}$ Tal medida protetiva guarda semelhança com a medida cautelar diversa da prisão prevista no art. 319, inc. III, do Código de Processo Penal, in verbis: "proibição de manter contato com pessoa determinada quando, por circunstâncias relacionadas ao fato, deva o indiciado ou acusado dela permanecer distante".

${ }^{24}$ STJ, AgInt no AREsp 608.061/PE, Rel. Ministro SEBASTIÃO REIS JÚNIOR, SEXTA TURMA, julgado em 17/05/2016, DJe 09/06/2016.

25 STJ, HC 352.167/DF, Rel. Ministro NEFI CORDEIRO, SEXTA TURMA, julgado em 09/08/2016, DJe 19/08/2016; HC 350.295/SP, Rel. Ministro ANTONIO SALDANHA PALHEIRO, SEXTA TURMA, julgado em 19/04/2016, DJe 03/05/2016.

${ }^{26}$ STJ, HC 298.499/AL, Rel. Ministro REYNALDO SOARES DA FONSECA, QUINTA TURMA, julgado em 01/12/2015, DJe 09/12/2015.
}

Revista de Direito Brasileira | São Paulo, SP | v. 17 | n. 7 | p. 221 - 244 | Mai./Ago. 2017 
judicial sobre perda ou suspensão de direito (art. 359 do Código Penal) ${ }^{27}$. A propósito, prevê o Enunciado $\mathrm{n}^{\mathrm{o}} 07$ do Conselho Permanente de Violência Doméstica e Familiar (COPEVID) do Grupo Nacional de Defesa dos Direitos Humanos (GNDH), vinculado ao Conselho Nacional de Procuradores Gerais de Justiça do Ministério Público dos Estados e da União: " $O$ descumprimento das medidas protetivas de urgência configura, em tese, crime de desobediência, cuja competência para processar e julgar é dos Juizados Especiais de Violência Doméstica, em razão da conexão e pelo fato de a mulher ser sujeito passivo secundário do delito, sofrendo diretamente as consequências do descumprimento".

E, se a situação também envolver crime de violência doméstica e familiar contra a mulher, na hipótese de existir inquérito policial ou ação penal em andamento, será possível a decretação de prisão preventiva, com fundamento no art. 313, inc. III, do Código de Processo Penal (introduzido pelo art. 42 da Lei Maria da Penha e posteriormente ratificado pela Lei 12.403/2011), se presentes os requisitos do art. 312 do CPP (a fim de se superar a presunção de não-culpabilidade do art. $5^{\circ}$, inc. LVII, da CF) ${ }^{28}$. Por outro lado, não presentes os requisitos do art. 312 do CPC, é possível deferir habeas corpus para determinar a soltura do suposto agressor, sem prejuízo de serem mantidas as medidas protetivas de urgência determinadas pelo juiz ${ }^{29}$.

As medidas protetivas de urgência previstas na Lei Maria da Penha podem ser pleiteadas de forma autônoma para fins de cessação ou acautelamento de violência doméstica contra a mulher $^{30}$. Desse modo, podem ser aplicadas isolada ou cumulativamente (art. 19, $\S 1^{\circ}$., da Lei 11.340/2006). Observados os seus requisitos específicos, também não dependem da existência, real ou potencial, de inquérito policial, processo criminal ou ação principal contra o suposto agressor.

Com isso, as medidas protetivas de urgência podem ter caráter satisfativo, posto que visam a proteção das mulheres em situação de violência doméstica e familiar, podendo estar voltadas a cessar a prática, a repetição ou a continuação do ilícito ou, ainda, para remover os efeitos concretos da conduta ilícita, sem servirem como garantia necessária da eficácia prática da tutela principal, isto é, para a preparação de qualquer ação judicial (DIAS, 2015, p.141). Aliás, seria contrário ao sentido protetivo da Lei Maria da Penha se, por exemplo, após o afastamento do agressor do domicílio, em razão das agressões praticadas, tivesse o direito de retornar ao lar, em razão da ação principal não ter sido ajuizada após 30 (trinta) dias da efetivação da medida ${ }^{31}$. Portanto, as medidas protetivas de urgência da Lei 11.340/2006 - a exemplo das medidas cautelares no âmbito do direito de família, como os alimentos provisionais ${ }^{32} \mathrm{e}$ a separação de

\footnotetext{
${ }^{27}$ STJ, AgRg no REsp 1528271/DF, Rel. Ministro JORGE MUSSI, QUINTA TURMA, julgado em 13/10/2015, DJe 21/10/2015. Em sentido contrário: STJ, HC 314.669/RS, Rel. Ministro ERICSON MARANHO (DESEMBARGADOR CONVOCADO DO TJ/SP), SEXTA TURMA, julgado em 18/02/2016, DJe 01/03/2016; AgRg no HC 292.158/RS, Rel. Ministro ROGERIO SCHIETTI CRUZ, SEXTA TURMA, julgado em 05/11/2015, DJe 23/11/2015. Este posicionamento deve ser objeto de crítica, pois o próprio Código Penal tipifica a desobediência da ordem judicial como crime, sendo possível a utilização de meios penais para assegurar o cumprimento de medidas civis. Caso contrário, não faria sentido a regra do art. 313, inc. III, do Código de Processo Penal que permite a decretação da prisão preventiva justamente para garantir a execução das medidas protetivas de urgência.

${ }^{28}$ STF, HC 101309, Relator(a): Min. AYRES BRITTO, Primeira Turma, julgado em 24/03/2010, DJe-081 DIVULG 06-05-2010 PUBLIC 07-05-2010 EMENT VOL-02400-03 PP-00600.

${ }^{29}$ STJ, RHC 68.567/MG, Rel. Ministro NEFI CORDEIRO, SEXTA TURMA, julgado em 02/06/2016, DJe $16 / 06 / 2016$.

${ }^{30}$ STJ, REsp 1419421/GO, Rel. Ministro LUIS FELIPE SALOMÃO, QUARTA TURMA, julgado em 11/02/2014, DJe 07/04/2014.

${ }^{31}$ BECHARA, Júlia Maria Seixas. Violência doméstica e natureza jurídica das medidas protetivas de urgência. Disponível em: < http://www.ibdfam.org.br/novosite/artigos/detalhe/689>. Acesso em 30/08/2016.

${ }^{32}$ Os alimentos provisionais são satisfativos e definitivos, embora sejam provisórios. Isso significa que, uma vez prestados, são irrepetíveis, embora a decisão judicial que os concedeu seja provisória, podendo ser revista ou reformada, o que gerará a cessação para o futuro dos alimentos concedidos. Cfr. SILVA, Ovídio A. Baptista da. Curso de processo civil. Vol. 2. $4^{\text {a }}$ ed. Rio de Janeiro: Forense, 2008. p. 71-72. Portanto, os efeitos gerados pela concessão da medida protetiva de urgência podem ser satisfativos e definitivos, embora o julgamento seja provisório.

Revista de Direito Brasileira | São Paulo, SP | v. 17 | n. 7 | p. 221 - 244 | Mai./Ago. 2017
} 
corpos, que não perdem sua eficácia se a ação não for ajuizada no prazo legal (e, por isso, não se submetem ao art. 308 do NCPC, correspondente ao art. 806 do $\mathrm{CPC} / 73)^{33}$ - podem ter natureza satisfativa, isto é, sem prazo de eficácia, podendo perdurar indefinidamente, enquanto persistir a situação de risco (DIAS, 2015, p.141).

Além disso, deve ser aplicada às medidas protetivas de urgência da Lei Maria da Penha a técnica processual da estabilização da tutela antecipada prevista no art. 304 do Novo Código de Processo Civil. Isso porque as medidas protetivas de urgência podem ser concedidas liminarmente, não dependendo da audiência das partes e da manifestação prévia do Ministério Público (art. 19, $\S 1^{\circ}$., da Lei 11.340/2006).

O objetivo da técnica adotada no art. 304 do NCPC é sumarizar, a um só tempo, a cognição e o procedimento, tornando eventual e facultativo o exercício da cognição exauriente para resolver os conflitos de interesses por meio da intervenção do Estado-Juiz. Para isso, deve-se tratar de hipótese de concessão de tutela antecipada inaudita altera parte, requerida expressamente pela mulher em situação de violência doméstica e familiar (art. 303, §5 $5^{\circ}$ NCPC), em caráter antecedente e autônomo, e o réu (agressor) não tenha contra ela se insurgido (SICA, 2015, p. 180).

Desse modo, se a medida protetiva de urgência for em caráter antecedente, concedida pelo juiz inaudita altera parte e a parte contrária, citada e intimada para a audiência de conciliação ou mediação na forma do art. 334 do NCPC (art. 303, §1 ${ }^{\circ}$, inc. II, NCPC) não interpuser agravo de instrumento (art. 1.015, inc. I, NCPC), a tutela jurisdicional antecipada mantém sua eficácia por tempo indeterminado e, portanto, se estabiliza, com a consequência da extinção do processo (art. 304, $\S 1^{\circ}, \mathrm{NCPC}$ ). Por exemplo, concedida a medida protetiva de urgência de prestação de alimentos provisórios (art. 22, inc. V, da Lei 11.340/2006), em caráter antecedente, a inércia do réu (agressor) em não impugnar o provimento antecipatório, faz com que a ordem de pagamento permaneça em vigor por tempo indeterminado, independentemente da declaração definitiva da existência do direito de alimentos (TALAMINI, 2012, p.121). Diante da estabilização da medida de urgência, inverte-se o ônus da instauração de um processo de cognição exauriente, a exigir, por parte do réu, a propositura de ação para obter o reconhecimento da inexistência do dever de pagar alimentos.

Nesse sentido, vale destacar o Enunciado $n^{\circ} 32$ do Conselho Permanente de Violência Doméstica e Familiar (COPEVID) do Grupo Nacional de Defesa dos Direitos Humanos (GNDH), vinculado ao Conselho Nacional de Procuradores Gerais de Justiça do Ministério Público dos Estados e da União: "Quando as Medidas Protetivas de Urgência, previstas na Lei $n^{o}$ 11.340/2006, tiverem natureza cível, podem ser concedidas como tutela provisória de urgência, nos termos dos artigos 300 e seguintes do CPC (Lei $n^{\circ}$ 13.105/2015), inclusive o regramento da estabilização da tutela provisória prevista nos artigos 303 e 304”.

A natureza provisória das medidas protetivas de urgência decorre da cognição sumária necessária ao seu deferimento ou indeferimento judicial, podendo ainda ser substituídas a qualquer tempo por outras de maior eficácia (art. 18, $\S 2^{\circ}$, da Lei 11.340/2006). Ficam submetidas, por força do art. 13 da Lei Maria da Penha, a depender da natureza civil ou penal, aos procedimentos estabelecidos no Código de Processo Penal ou no Código de Processo Civil.

No âmbito civil, as decisões que deferem ou indeferem as medidas protetivas de urgência se submetem ao sistema recursal do NCPC, estando sujeitas ao recurso de agravo de instrumento quando deferidas em decisões interlocutórias (art. 1.015, inc. I, do NCPC) ou à apelação, quando confirmadas, concedidas ou revogadas na própria sentença (arts. 1.009, caput, e 1.012 , inc. V, NCPC).

\footnotetext{
${ }^{33}$ STJ, RHC 33.395/MG, Rel. Ministro PAULO DE TARSO SANSEVERINO, TERCEIRA TURMA, julgado em 04/10/2012, DJe 05/10/2012; REsp 436.763/SP, Rel. Ministro HUMBERTO GOMES DE BARROS, TERCEIRA TURMA, julgado em 27/11/2007, DJ 06/12/2007, p. 312.
}

Revista de Direito Brasileira | São Paulo, SP | v. 17 | n. 7 | p. 221 - 244 | Mai./Ago. 2017 


\section{CONCLUSÃO}

Nesse breve estudo sobre a Lei Maria da Penha buscou-se apenas apontar algumas problematizações ainda atuais sobre o tema, para se chegar a seguinte autocrítica: após mais de 10 (dez) anos de vigência da Lei 11.340/2006 conquistou-se muito, mas não o suficiente para alterar a triste realidade social brasileira. Não obstante isso, os resultados alcançados ao trazer o debate sobre a questão de gênero são inegáveis, além de demonstrar uma preocupação legítima do Estado Brasileiro com a perspectiva feminista da e na sociedade.

A Lei Maria da Penha, ao estabelecer diferenciação legal quanto ao gênero, superou a perspectiva da mera igualdade formal, para efetivar o disposto no art. $226, \S 8^{\circ}$, da Constituição Federal e reafirmar as conquistas trazidas pela Convenção Internacional sobre a Eliminação de todas as formas de Discriminação contra a Mulher e pela Convenção Interamericana para Prevenir, Punir e Erradicar a Violência Contra a Mulher (Convenção de Belém do Pará).

A Lei 11.340/2006 é um instrumento de ação afirmativa que, por meio de discriminações positivas, procurou alterar a estrutura patriarcal e de dominação masculina histórica, com a previsão de medidas de igualdade material a partir da percepção legal da diferença entre os gêneros.

Ao conjugar normas de natureza penal e civil, desenvolveu técnicas processuais diferenciadas para a proteção das mulheres em situação de violência doméstica e familiar, sem prejuízo da aplicação das regras não conflitantes contidas nos Códigos de Processo Penal e Processo Civil e na legislação específica relativa à criança, ao adolescente e ao idoso (art. 13 da lei 11.340/2006).

Com isso, rompeu com a tradição jurídica, voltada à manutenção do status quo e da reprodução das estruturas de dominação vigentes, para promover a inclusão social das minorias com o saneamento das desigualdades históricas.

Embora a Lei 11.340/2006 não seja a panaceia jurídica para as questões dos Direitos das Mulheres, é um exemplo dessa utopia democratizante ambicionada, pelo constitucionalismo inclusivo (CAMBI; LIMA, 2014, p. 11-35), para uma sociedade que, a partir do ambiente doméstico e familiar, perceba o outro na sua ampla condição humana e o respeite enquanto sujeito igual e de deveres e direitos.

Entretanto, apesar da Lei Maria da Penha ser uma legislação inovadora, o Mapa da Violência 2015 evidencia que o Brasil passou de $7^{\circ}$ para $5^{\circ}$ lugar no índice de feminicídios ${ }^{34}$. São 4,8 mortes por 100.000 habitantes. Aqui, mata-se 48 vezes mais que no Reino Unido, 24 vezes mais que na Irlanda e 16 vezes mais que no Japão. O Brasil fica atrás apenas de El Salvador $(8,9)$, Colômbia (6,3), Guatemala $(6,2)$ e Federação Russa $(5,3)$ mortes por 100.000 habitantes.

Portanto, mais de 10 (dez) anos após a entrada em vigor da Lei 11.340/2006, a Lei Maria da Penha ainda está distante de resolver ou minimizar a violência doméstica e familiar contra a mulher no Brasil. É indispensável não apenas a correta interpretação e aplicação dessa lei, mas também investimentos e políticas públicas integradas capazes de promover resultados melhores e, a médio prazo, transformar a sociedade brasileira pelo enraizamento da cultura de respeito aos direitos humanos.

\footnotetext{
34 FERNANDES, Valéria Diez Scarance. "Genocídio" no Brasil: 5 país que mais mata mulheres no mundo. Disponível em: http://www.cartaforense.com.br/conteudo/artigos/generocidio-no-brasil-5 ${ }^{\circ}$-pais-que-mais-matamulheres-no-mundo/16043. Acesso em 05 de setembro de 2016.
} 


\section{REFERÊNCIAS BIBLIOGRÁFICAS}

ALVES, Fernando de Brito. Para uma fundamentação dos direitos de minorias em tempos de transição paradigmática. Dissertação de mestrado (ciências jurídicas). Jacarezinho: Universidade Estadual do Norte do Paraná, 2009.

- Constituição e participação popular: a construção histórico-discursiva do conteúdo jurídico-político da democracia como direito fundamental. Curitiba: Juruá, 2013.

ÁVILA, Thiago André Pierobom (Coord.). Modelos europeus de enfrentamento à violência de gênero. Experiências e representações sociais. Brasília: Escola ESMPU, 2014.

ANTUNES ROCHA, Carmem Lúcia. Ação afirmativa: o conteúdo democrático do princípio da igualdade jurídica. Revista trimestral de direito público, vol. 15, 1996.

BAKER, Milena Gordon. A tutela da mulher no direito penal brasileiro. Rio de Janeiro: Lumen Juris, 2015.

BEAUVOIR, Simone. O segundo sexo. Vol. 1. $3^{\mathrm{a}}$ ed. Rio de Janeiro: Nova Fronteira, 2016.

. O segundo sexo. Vol. 2. $3^{\text {a }}$ ed. Rio de Janeiro: Nova Fronteira, 2016.

BECHARA, Júlia Maria Seixas. Violência doméstica e natureza jurídica das medidas protetivas de urgência. Disponível em: < http://www.ibdfam.org.br/novosite/artigos/detalhe/689>. Acesso em 30/08/2016.

BIANCHINI, Alice. Lei Maria da Penha: Lei 11.340/2006: aspectos assistenciais, protetivos e criminais da violência de gênero. $3^{\mathrm{a}}$ ed. São Paulo: Saraiva, 2016.

BIROLI, Flávia; MIGUEL, Luis Felipe. Feminismo e política. São Paulo: Boitempo, 2014.

BOURDIEU, Pierre. A Distinção: Crítica Social do Julgamento. São Paulo:Edusp; Porto Alegre:Zoak. 2007.

. A Dominação Masculina. Rio de Janeiro: Bertrand Brasil, 2012.

CAMBI, Eduardo; LIMA, Jairo Néia. Constitucionalismo inclusivo: o reconhecimento do direito fundamental à inclusão social. Revista de direito privado, vol. 60, out./dez./2014.

CAMBI, Eduardo. Neoconstitucionalismo e Neoprocessualismo: Direitos Fundamentais, Políticas Públicas e Protagonismo Judiciário. São Paulo: Almedina, 2016.

CAMPOS, Carmen Hein de; CARVALHO, Salo de. Tensões atuais entre a criminologia feminista e a criminologia crítica: a experiência brasileira. Org. Carmen Hein de Campos. In: Lei Maria da Penha comentada em uma perspectiva jurídico-feminista. Rio de Janeiro: Lumen Juris, 2011. 
CAVALCANTI, Stela Valéria de Farias. Violência doméstica. Análise da Lei "Maria da Penha", $n^{o}$ 11.340. $4^{\mathrm{a}}$ ed. Salvador: Juspodivm, 2012.

CLÉVE, Clèmerson. Merlin. Ações afirmativas, justiça e igualdade. Revista jurídica do Ministério Público do Estado do Paraná, vol. 3, dez./2015.

CORRÊA, Rúbian Coutinho (Org.). O enfrentamento à violência doméstica e familiar contra a mulher: uma construção coletiva. Contribuições dos Ministérios Públicos Estaduais e da União para o entendimento da Lei $n^{\circ}$ 11.340/2006 - Maria da Penha. Brasília: Conselho Nacional de Procuradores Gerais dos Ministérios Públicos dos Estados e da União, 2011.

CUNHA, Rogério Sanches; PINTO, Ronaldo Batista. Violência doméstica. Lei Maria da Penha comentada artigo por artigo. $6^{\mathrm{a}}$ ed. São Paulo: RT, 2015.

DAHL, Tove Stang. O direito das mulheres: Uma introdução à teoria do direito feminista. Fundação Calouste Gulbenkian: Lisboa, 1993.

DIAS. Maria Berenice. Violência doméstica e as uniões homoafetivas. Revista Jus Navigandi, Teresina, ano 11, n. 1185, 26 set. 2006. Disponível em: <https://jus.com.br/artigos/8985>. Acesso em:1 set. 2016.

. A Lei Maria da Penha na justiça. $4^{\mathrm{a}}$ ed. São Paulo: RT, 2015.

DIDIER JÚNIOR, Fredie; OLIVEIRA, Rafael. Aspectos processuais civis da Lei Maria da Penha (Violência doméstica e familiar contra a mulher). Revista de processo, vol. 160, jun./2008.

FERNANDES, Valéria Diez Scarance. Lei Maria da Penha. O processo penal no caminho da efetividade. São Paulo: Atlas, 2015.

- "Genocídio" no Brasil: $5^{\circ}$ país que mais mata mulheres no mundo. Disponível em: http://www.cartaforense.com.br/conteudo/artigos/generocidio-no-brasil-5º-pais-que-mais-matamulheres-no-mundo/16043. Acesso em 05 de setembro de 2016.

GARCIA, Emerson. Proteção e inserção da mulher no Estado de Direito: A Lei Maria da Penha. De Jure - Revista jurídica do Ministério Público do Estado de Minas Gerais, vol. 12, jan./jun./2009.

GOMES, Joaquim Benedito Barbosa. Ação afirmativa \& princípio constitucional da igualdade. Rio de Janeiro: Renovar, 2001.

JESUS, Damásio. Violência contra a mulher. São Paulo: Saraiva, 2010.

LINO, Alice de Carvalho. Belo e sublime: a mulher e o homem na filosofia de Immanuel Kant. Dissertação (Mestrado em Filosofia). Ouro Preto: Universidade Federal de Ouro Preto, 2008.

MARINONI, Luiz Guilherme. Controle do poder executivo do juiz. Revista de processo, vol. 125 , set./2005. 
. Tutela contra o ilícito: uma análise do artigo 497, parágrafo único do CPC/2015. In: Direito e justiça. Estudos em homenagem a Gilberto Giacoia. Coord. Eduardo Cambi e Alencar Frederico Margraf. Curitiba: Ministério Público do Estado do Paraná, 2016.

MONTE, Nalida Coelho. As medidas protetivas de urgência da Lei 11.340/06 não exigem, para sua concessão e manutenção, a existência de boletim de ocorrência, representação criminal ou procedimento criminal. Disponível em: < http://http://www.defensoria.sp.def.br/dpesp/Conteudos/Materia/MateriaMostra.aspx?idItem=658 91\&idModulo=9706\#_ftn7>. Acesso em 30/08/2016.

MONTENEGRO, Marilia. Lei Maria da Penha: uma análise criminológico-crítica. Rio de Janeiro: Revan, 2015.

MORATO, Alessandra Campos; SANTOS, Claudiene; RAMOS, Maria Eveline Cascardo; LIMA, Suzana Canaez da Cruz. Análise da relação sistema de justiça criminal e violência doméstica contra a mulher. Brasília: ESMPU, 2009.

MOREIRA, Rômulo de Andrade. Lei Maria da Penha: aspectos criminológicos, de política criminal e do procedimento penal. $3^{\mathrm{a}}$ ed. Curitiba: Juruá, 2014.

PENHA, Maria. Sobrevivi... posso contar. $2^{\mathrm{a}}$ ed. Fortaleza: Editora Armazém da Cultura, 2012.

PERROT, Michelle. Minha História das Mulheres. 2a ed. São Paulo: Contexto, 2016.

PIERUCCI, Antônio Flávio. Ciladas da diferença. $3^{\text {a }}$ ed. São Paulo: Programa de Pós-Graduação em Sociologia da FFLCH-USP/Editora 34, 2013.

PIOVESAN, Flávia. Temas de direitos humanos. 8ª ed. São Paulo: Saraiva, 2015.

PORTO, Pedro Rui da Fontoura. Violência doméstica e familiar contra a mulher. $3^{\mathrm{a}}$ ed. Porto Alegre: Livraria do Advogado, 2014.

SICA, Heitor Vitor Mendonça. Doze problemas e onze soluções quanto à chamada "estabilização da tutela antecipada". In: Procedimentos especiais, tutela provisória e direito transitório. Vol. 4. Org. Lucas Buril de Macêdo, Ravi Peixoto e Alexandre Freire. Salvador: Juspodivm, 2015.

SILVA, Ovídio A. Baptista da. Curso de processo civil. Vol. 2. 4 ${ }^{\mathrm{a}}$ ed. Rio de Janeiro: Forense, 2008.

TALAMINI, Eduardo. Tutela de urgência no projeto de Novo Código de Processo Civil: a estabilização da medida urgente e a "monitorização" do processo civil brasileiro. Revista de processo, vol. 209, jul./2012.

TIBURI, Marcia. Aulas online, no curso Filosofia Feminista. Disponível em: http:/espacorevistacult.edools.com/curso/filosofia-feminista-por-marcia-tiburi. Acesso em 22/08/2016. 